\title{
Wpływ interwencjonizmu państwowego w XX wieku na współczesną kondycję gospodarczą regionów włoskich
}

\section{The impact of state interventionism in the 20th century on the contemporary economic condition of Italian regions}

\begin{abstract}
Streszczenie: Artykuł traktuje o znaczeniu interwencji państwa włoskiego w XX wieku w wybrane sektory gospodarki (w ujęciu regionalnym) na późniejszą sytuację społeczno-ekonomiczną regionów. Ze względu na obserwowane współcześnie bardzo duże zróżnicowanie gospodarcze regionów, postawiono sobie pytanie, czy i w jakim stopniu centralna polityka państwa włoskiego okresu postzjednoczeniowego wpłynęła na występujące dziś dysproporcje? Artykuł składa się z trzech zasadniczych części: w pierwszej nakreślono współczesne zróżnicowanie społeczno-ekonomiczne regionów, w drugiej przedstawiono kondycję gospodarczą regionów po zjednoczeniu kraju oraz stanowisko państwa i podjęte przez nie działania, w tym programy naprawcze służące poprawie warunków społeczno-ekonomicznych regionów, w trzeciej części dokonano oceny trafności i zasadności realizacji tych działań w kontekście aktualnej sytuacji gospodarczej kraju. Celem artykułu jest wskazanie na znaczenie roli polityki państwa i decyzji podjętych w przeszłości na współczesną kondycję gospodarczą regionów włoskich. Tym samym autor na podstawie kwerendy literatury oraz przy zastosowaniu wybranych metod statystycznych podejmuje próby wyjaśnienia permanentnych, a w niektórych obszarach nadal pogłębiających się, różnic w rozwoju społeczno-ekonomicznym włoskich regionów, ze szczególnym uwzględnieniem wpływu działań politycznych podjętych po zjednoczeniu kraju.
\end{abstract}

\begin{abstract}
The article deals with the importance of the Italian state intervention in the 20th century in selected sectors of the economy (in regional terms) on the subsequent socio-economic situation of the regions. Due to the observed today very large differentiation of the regions, the question is whether and to what extent the central policy of the Italian state of the post-unification period influenced the disproportions occurring today? The article consists of three main parts: the first outlines the contemporary socio-economic differentiation of the regions, the second presents the economic condition of the regions after the unification of the country, and the position of the state, and the measures it has taken, including repair programs used to improve the socio-economic conditions of the regions, the third part assesses the relevance and legitimacy of the implementation of these measures in the context of the current situation of the country. The aim of the article is to indicate the importance of the role of state policy, and the decisions taken in the past on the contemporary economic condition of Italian regions. Thus, the author attempts to explain the permanent, and in some areas still deepening, differences in the socio-economic development of Italian regions.
\end{abstract}


Słowa kluczowe: Mezzogiorno; nacjonalizacja; przemysł; rozwój regionalny; sektor publiczny; Trzecie Włochy - Terza Italia; Włochy

Keywords: industry; Italy; nationalisation; public sector; regional development; Southern Italy; Third Italy

Otrzymano: 21 listopada 2021

Received: 21 November 2021

Zaakceptowano: 29 listopada 2021

Accepted: 29 November 2021

\section{Sugerowana cytacja / Suggested citation}

Noviello, M. (2021). Wpływ interwencjonizmu państwowego w XX wieku na współczesną kondycję gospodarczą regionów włoskich. Prace Komisji Geografii Przemysłu Polskiego Towarzystwa Geograficznego, 35(4), 227-248. doi: https://doi.org/10.24917/20801653.354.14

\section{WSTĘP}

Współczesną gospodarkę krajów wysoko rozwiniętych gospodarczo charakteryzuje wzmocnienie roli jednostek regionalnych kosztem osłabienia skuteczności i znaczenia państwa w osiąganiu wysokiego poziomu rozwoju społeczno-gospodarczego. Taki trend jest z jednej strony wynikiem postępujących procesów globalizacji, a z drugiej znacznie większą elastycznością i zdolnością adaptacji jednostek regionalnych do zmieniających się warunków rynkowych (Stokowska, 2006). Badania wykazały też, że społeczności lokalne są bardziej skłonne do akceptacji zmian, dostosowania się i aktywnej partycypacji w nowej rzeczywistości, jeśli ta w bezpośredni sposób będzie wpływała na jakość życia i warunki społeczno-ekonomiczne w regionie (Majorek, 2017; Pawlewicz, K. Pawlewicz, A., 2010; Pietraszko-Furmanek, 2012; Słupik, 2016). Takie działania w skali kraju są o wiele trudniejsze, dlatego coraz częściej w literaturze przedmiotu podejmowane są rozważania nad znaczeniem i ogromną rolą polityki regionalnej, a wręcz pomijany jest wpływ państwa i jego działania na rzecz rozwoju gospodarki jako zintegrowanej całości. Należy zauważyć, że w pierwszych latach po drugiej wojnie światowej polityka regionalna w krajach Europy Zachodniej była traktowana jako część gospodarki państwa, dlatego jej postulaty były realizowane w oparciu o keynezowskie i fordowskie założenia. Pierwsze z nich głosiły konieczność silnej ingerencji państwa w rozwój poszczególnych regionów, drugie natomiast wskazywały wybrane gałęzie przemysłu (wówczas ciężki i petrochemiczny) jako elementy decydujące o rozwoju gospodarki państwa. Ponadto, w paradygmacie fordowskim zakładano, że działalność gospodarcza powinna być lokowana w miejscach, gdzie możliwe jest zapewnienie następujących warunków: obecność dużych przedsiębiorstw, centrów przemysłowych, dostęp do dużych zasobów ludzkich, niskie są koszty pracy, istnieje łatwość w nabywaniu surowców, niskie są koszty transportu, infrastruktura transportu masowego jest w stanie zapewnić ciągłość produkcji i występuje dostatek mocy (Stokowska, 2006). Takie rozumienie rozwoju regionalnego skłaniało władze centralne do realizacji działań polegających na finansowaniu bardzo kosztownych inwestycji w regionach słabiej rozwiniętych. Z tego względu, na obszarach o znacznym zapóźnieniu gospodarczym lokowane były wielkie państwowe kompleksy przemysłowe, uruchomiano dotacje, subwencje, ulgi podatkowe dla prywatnych inwestorów. Państwo podejmowało się również finansowania tzw. infrastruktury ciężkiej. Wszystkie te działania miały zapewnić gospodarce krajowej stabilność rozwoju, a dla poszczególnych regionów miała to być szansa na wyrównanie dysproporcji w sferze społecznej i ekonomicznej. Jednak obok 
podejścia keynezowskiego i fordowskiego, dość powszechnym było podejście neoliberalne, które postulowało bardziej za tym, aby stymulować postawy przedsiębiorcze przez obniżenie kosztów pracy czy kapitału. Jednak takie rozwiązania nie przynosiły pozytywnych rezultatów rozwoju gospodarczego w regionach znacznie zapóźnionych gospodarczo. Przeciwnie, jak zauważa Stokowska (2006) twarde prawa wolnego rynku powodowały odpływ środków i zasobów do regionów o lepszej kondycji gospodarczej.

W wyniku kryzysu strukturalnego lat 70. XX wieku w krajach Europy Zachodniej, w tym we Włoszech, niemożliwym było kontynuowanie przez rządy centralne polityki interwencjonizmu na tak szeroką skalę, a miejsce znalazł nowy nurt - postfordyzm. Jego postulatem był rozwój przemysłu nowych technologii w oparciu o wykorzystanie zasobów niematerialnych (wiedza, informacja, innowacja). Ponadto zaobserwowano, że regiony peryferyjne, w gospodarkę których państwo nie ingerowało w tak dużym stopniu, same podejmowały skuteczne działania, a korzyści (w sferze społecznej i ekonomicznej) obserwowano tam w stosunkowo krótkim czasie. W efekcie paradygmat postfordowski ukierunkowany był na rozwój polityki regionalnej w takiej konfiguracji i według zasad lokalizacji przedsiębiorstw i usług, jaka obowiązuje współcześnie.

We Włoszech od początku powstania państwa (1861) obserwuje się odmienność terytorialną obowiązujących tam paradygmatów rozwoju gospodarczego, które od początku lat 70. XX wieku uległy dezaktualizacji i przyjęto jeden nurt rozwoju - postfordyzm, obowiązujący do początku lat 90 . XX wieku. W kolejnych latach podejmowano działania na rzecz polityki regionalnej, co zostało uregulowane ostatecznie nowelizowanymi w 2001 roku zapisami w V Tytule Konstytucji Włoch. Jednak to działania i interwencje nie ostatnich dziesięcioleci, ale również te podjęte dużo wcześniej, bo wkrótce po zjednoczeniu, przez następujące po sobie centralistyczne władze (do $1946 \mathrm{r}$. monarchii Sabaudów, a kolejno i po dzisiaj rządy republikańskie) w stosunku do poszczególnych obszarów zjednoczonych Włoch stanowią, zdaniem autora, wyjaśnienie dla tak różnej kondycji gospodarczej regionów. Zauważono bowiem, że prowadzona po zjednoczeniu polityka faworyzowała rozwój gospodarczy niektórych obszarów, a tym samym te same władze stosowały represje lub formy pomocy, które w pewnym stopniu spowodowały, że działające na niewielką jeszcze skalę organizacje przestępcze, znalazły doskonałe warunki dla dalszego rozwoju.

Celem artykułu jest wskazanie na znaczenie roli polityki państwa i decyzji podjętych w przeszłości na współczesną kondycję gospodarczą regionów włoskich. Tym samym autor podejmuje próby wyjaśnienia permanentnych, a w niektórych obszarach nadal pogłębiających się różnic w rozwoju społeczno-ekonomicznym włoskich regionów. Badania prowadzono na podstawie kwerendy dostępnej literatury oraz przez wykorzystanie wybranych metod statystycznych, które pozwoliły na zobrazowanie istniejącego zróżnicowania społeczno-ekonomicznego pomiędzy włoskimi regionami.

\section{PODZIAŁ ADMINISTRACYJNO-PRAWNY I ZARYS SYTUACJI SPOŁECZNO-EKONOMICZNEJ REGIONÓW WŁOSKICH}

Współczesne Włochy są republiką o charakterze unitarnym, jednak taka forma państwa obowiązuje od referendum konstytucyjnego, które odbyło się po drugiej wojnie światowej (w 1946 r.). Wówczas Włosi zrezygnowali z władzy monarchii Sabaudów na rzecz republiki konstytucyjnej. Wtedy też w zapisach Konstytucji tego kraju po raz pierwszy określono regiony jako formy administracyjno-prawne, a w kolejnych dziesięcioleciach 
w wyniku reform z lat 70., 90. i nowelizacji V Tytułu Konstytucji stopniowo dążono do zwiększenia autonomii regionom, prowincjom, gminom i miastom metropolitarnym, czyli jednostkom na wszystkich szczeblach obowiązującego współcześnie podziału terytorialnego. Obecnie w tym kraju obowiązuje podział na 20 regionów, z czego 15, z punktu widzenia ustroju, to regiony zwykłe, natomiast pozostałe 5 to regiony o statucie specjalnym. Wydzielenie tych drugich uzasadniono ich wyspiarskim charakterem (Sardynia i Sycylia) lub przygranicznym położeniem i wynikającymi z tego wpływami kulturowo-językowymi ludności krajów sąsiednich (ludności niemieckojęzycznej w Trydencie-Górnej Adydze, francuskiej w Dolinie Aosty i słoweńskiej w Friuli-Wenecji Julijskiej). Znaczna decentralizacja władzy i kompetencji na poszczególnych szczeblach podziału administracyjnego kraju stanowi cechę charakterystyczną polityki gospodarczej tego kraju. Z tego też względu Włochy nazywane są powszechnie państwem regionalnym, choć z prawnego punktu widzenia nadal pozostają republiką unitarną. Postrzeganie Włoch przez pryzmat regionalny czasem prowadzi do błędnej interpretacji jakoby najwyższym poziomem gospodarki tego kraju był ten regionalny. Dzieje się też tak ze względu na występowanie bardzo dużych różnic w rozwoju społeczno-ekonomicznym między poszczególnymi regionami, dlatego tak trudno o integralność i spójność włoskiej polityki gospodarczej. Sytuacja gospodarcza włoskich regionów wskazuje na bardzo duże dysproporcje, zwłaszcza w ujęciu komparatywnym między jednostkami tego samego rzędu. W celu przedstawienia kondycji społecznej i ekonomicznej mieszkańców poszczególnych regionów, zostaną przybliżone wybrane (zdaniem autora), najbardziej reprezentatywne dane potwierdzające owe różnice (poziom zatrudnienia, stopa bezrobocia, PKB per capita, średnia wielkość dochodów na jednego mieszkańca i ich wielkość w przeliczeniu na jednego członka rodziny). Znaczne dysproporcje występują biorąc pod uwagę rynek pracy, a zwłaszcza poziom zatrudnienia i skalę bezrobocia. Średni poziom zatrudnienia we Włoszech w 2020 roku wynosił $57,9 \%$, natomiast biorąc pod uwagę poszczególne regiony wartości te wykazują duże różnice. Najmniejszy odsetek pracujących występował w regionach południowych: Sycylia $(44,1 \%)$, Kampania (45,3\%), Kalabria $(45,6 \%)$ i Apulia $(49,4 \%)$. Najwyższy zaś odnotowano w Emilii-Romanii i Friuli-Wenecji Julijskiej (powyżej 75\%), ale również we wszystkich regionach północnej i środkowej części kraju zatrudnienie znajduje powyżej 65\% społeczeństwa. Równie niepokojące okazują się dane dotyczące poziomu bezrobocia, które w Kalabrii, na Sycylii i w Kampanii wynosiło w 2020 roku odpowiednio $21,6 \%, 21,5 \%$ i $20,4 \%$. Trudna sytuacja na regionalnym rynku pracy występuje również w Apulii (16\%) i na Sardynii (15,4\%). Na północy Włoch najniższe bezrobocie notuje się w prowincji Bolzano $(2,9 \%)$, Trento $(4,8 \%)$ oraz w regionach Lombardia (5\%), Emilia-Romania (5,9\%) i Wenecja Euganejska (6,4\%). Również pozostałe regiony na północy i w środkowej części kraju wykazują stosunkowo niską stopę bezrobocia (poniżej 8\%) (Toskania, Marche, Piemont, Umbria, Liguria). Natomiast biorąc pod uwagę średnią wielkość PKB per capita (wg aktualnych cen rynkowych) w 2019 roku wynosiła 28600 euro, przy czym zauważa się znaczne różnice regionalne i wyraźny podział na linii Północ-Południe. Również średnioroczny dochód na mieszkańca i średni dochód przypadający na jednego członka rodziny w ujęciu regionalnym są bardzo zróżnicowane (rycina 1). Wartość pierwszego z nich mieści się w przedziale od 28800 euro w Kalabrii do 41600 euro w prowincji Bolzano. W 2017 roku średnia krajowa dochodu w przeliczeniu na 1 obywatela wynosiła 35900 euro, a poniżej tej wartości znalazły się wszystkie regiony południowych Włoch oraz Toskania (34 900 euro) i Umbria (32 
500 euro). Najwyższe średnie dochody spośród regionów o statucie zwykłym uzyskują mieszkańcy Lombardii (40 400 euro), a za nimi kolejno Włosi zamieszkujący wszystkie regiony północnej części kraju. Średnia wartość dla regionów północno-zachodnich wynosi 39300 euro, a północno-wschodnich - 37600 euro. Natomiast średnia wartość dochodów mieszkańców Mezzogiorno wynosi 30900 euro, gdyż obok wspomnianej Kalabrii niskie dochody uzyskują również mieszkańcy Kampanii (30 700 euro) i Apulii (30 800 euro). W stosunku do roku 2016 wielkość dochodów wykazuje tendencję wzrostową, ale jej dynamika jest bardzo zróżnicowana w poszczególnych częściach kraju: wzrost o 1,4\% na północnym wschodzie, o 0,7\% na północnym zachodzie i w centrum oraz $0,3 \%$ na Południu i na wyspach. Najwyższy dochód na mieszkańca odnotowano w autonomicznej prowincji Bolzano (26 000 euro), w regionach Emilia-Romania i Lombardia (po 22900 euro). Najniższy zaś w Kalabrii, Kampanii i na Sycylii (odpowiednio 12 700; 13500 i 13600 euro). Mieszkańcy północno-zachodniej część kraju dysponują wartością nominalną dochodu w wysokości przekraczającej 22000 euro, czyli o ponad 60 \% wyższej od tej notowanej na Południu (14 000 euro).

Dane te wskazują jak dużym problemem dla prowadzenia spójnej polityki krajowej są występujące dysproporcje. Nasuwają się również pytania dotyczące kondycji gospodarczej poszczególnych jednostek terytorialnych (prowincji) po zjednoczeniu kraju, działań podjętych przez władze centralne na rzecz spójności gospodarki poszczególnych regionów i stanowiska państwa w stosunku do znacznego zapóźnienia gospodarczego południowej części kraju.

Rycina 1. Średnia wielkość dochodów we Włoszech przypadająca na jednego członka rodziny w 2017 r.

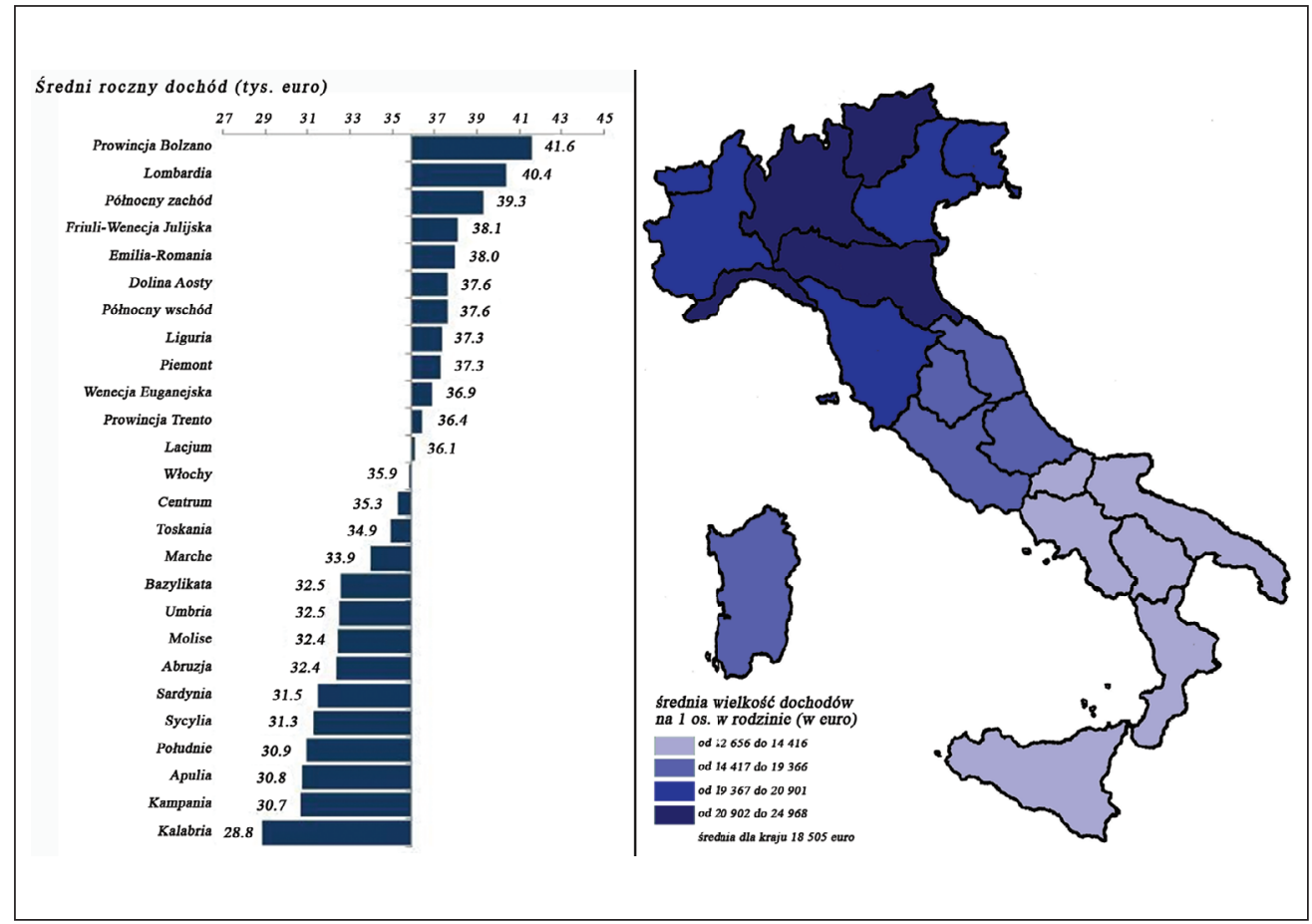

Źródło: opracowano na podstawie danych Istat $(2018,2019)$ 
KONDYCJA GOSPODARCZA WŁOSKICH REGIONÓW PO ZJEDNOCZENIU KRAJU ORAZ INTERWENCJONIZM PAŃSTWOWY JAKO ODPOWIEDŹ NA ICH POTRZEBY

Na sytuację gospodarczą regionów Włoch w największym stopniu wpłynął proces uprzemysłowienia, rozpoczęty jeszcze przed zjednoczeniem. Jednak w literaturze przedmiotu można doszukać się wielu innych przyczyn powstania różnic w rozwoju społeczno-gospodarczym zwłaszcza pomiędzy północną a południową częścią kraju. Wśród nich autorzy wymieniają m.in.: (1) przyczyny geograficzne (na północy korzystniejsze warunki dla rolnictwa - większy dostęp do wody, lepszej jakości gleby, sprzyjająca orografia terenu, łagodniejszy klimat), (2) sytuacja demograficzna i wielka migracja ludności z Południa w kilka lat po zjednoczeniu, (3) brak konkretnych programów gospodarczych dla pobudzenia rozwoju głównych gałęzi przemysłu, (4) wzrost cen produktów przemysłowych i stagnacja cen produktów rolnych. Takie warunki powodowały, że po zjednoczeniu państwa włoskiego znaczny wzrost gospodarczy odnotowano w północno-zachodniej jego części (między Turynem, Mediolanem i Genuą), czyli na obszarze tzw. trójkąta przemysłowego (triangolo industriale), współpracującego z firmami ze Szwajcarii, Francji i Niemiec. Pojawiające się oznaki nierówności między Północą a Południem były wówczas łagodzone m.in. przez konsekwencje wielkiej migracji (Noviello, 2021) oraz w późniejszych latach przez inicjatywy i programy mające na celu wzmocnienie gospodarki Południa (m.in. Plan Rozwoju dla Południa, Kasa Południa, Plan Vanoniego). Niemniej jednak o sukcesie w rozwoju przemysłu w północno-zachodniej części Włoch zadecydowało kilka czynników: (1) znacznie większe wsparcie ze strony państwa kluczowych wówczas gałęzi przemysłu zaraz po zjednoczeniu kraju, (2) duże zróżnicowanie gałęziowe przemysłu wynikające z wykorzystania technik pierwszej i drugiej rewolucji przemysłowej (odpowiednio: przemysł tekstylny, odzieżowy, spożywczy oraz mechanizacja, przemysł gumowy, elektryczny), (3) rozwój energetyki wodnej, (4) doskonała, jak na tamte czasy, sieć transportowa, (5) duże zasoby kapitału ludzkiego, (6) wzrost liczby zleceń państwowych w okresie pierwszej wojny światowej, (7) znaczna pomoc z budżetu państwa zaraz po zakończonej wojnie w celu ratowania dużych upadających fabryk, (8) subwencje państwowe w ramach powstałego Instytutu Odbudowy Przemysłu (Istituto per la Ricostruzione Industriale, IRI) w okresie kryzysu z 1929 roku, (9) wsparcie ze strony rządów faszystowskich rozwijającego się przemysłu autarkicznego, w tym dobrze już prosperującego na północnym zachodzie przemysłu chemicznego i aluminiowego, oraz ukierunkowanie Południa na rozwój znacznie mniej dochodowego rolnictwa, (10) pomoc w ramach realizacji Planu Marshalla, co zapoczątkowało produkcję masową w północno-zachodniej części kraju, (11) stałe finansowanie publiczne i ochrona przemysłu w tej części kraju, nawet w okresie wojny.

Można zakładać, że lista wymienionych czynników, które zdecydowały o lepszej kondycji gospodarczej Północy została wyczerpana, jednak zdaniem autora, dla wyjaśnienia tak drastycznych dysproporcji w rozwoju w obrębie jednego organizmu państwowego, nie można ograniczyć się tylko do reguł rozwoju gospodarczego. Należy bowiem sięgnąć do czasu, kiedy formowało się państwo włoskie, dokonać analizy decyzji i działań, jakie władze państwowe podjęły w stosunku do określonych części kraju, a zwłaszcza jego południowej części, odpowiadającej istniejącemu do 1861 roku Królestwu Obojga Sycylii. Jest to o tyle zasadne, że na podstawie analizy przestrzennej licznych wskaźników ekonomicznych, bardzo wyraźnie zaznacza się granica zasięgu 
rządów burbońskich, co współcześnie pokrywa się z terytorialnym zasięgiem biednego Południa. Względy te skłaniają ku temu, aby nakreślić sytuację społeczno-ekonomiczną tej części Włoch począwszy od momentu zjednoczenia.

Niewątpliwie po zjednoczeniu kraju na Południu notuje się znaczny wzrost aktywności zorganizowanych grup przestępczych (których działania za panowania dynastii Burbonów były dość ograniczone i w dużym stopniu utrzymywane pod kontrolą). Stało się tak również na skutek niedotrzymania przez nową władzę obietnic dyktatora Giuseppe Garibaldiego. Ten zdobywając Sycylię (i kolejno na północ pozostałe obszary korony burbońskiej) gwarantował ludności m.in. zachowanie dotychczasowej autonomii na wyspie, wprowadzenie ustroju republikańskiego oraz przeprowadzenie reformy rolnej gwarantującej chłopom własność ziemską (Janek, 2018). W efekcie nowe państwo włoskie potraktowało Sycylię i pozostałe regiony Południa niemal jako zdobycz wojenną i nałożyło na nie kontrybucję przeznaczoną na pokrycie części zadłużenia, jakie Piemont i Lombardia zaciągnęły kilka lat wcześniej na prowadzenie wojny z Cesarstwem Austrii. Dlatego w 1862 roku większość środków pieniężnych pozostałych po Burbonach i zdeponowanych w Banca delle Due Sicilie w wysokości około 105 mln dukatów w złocie (443 mln ówczesnych włoskich lirów) została przejęta przez skarb Królestwa Włoch (Janek, 2018). Dodatkowo zostały zwiększone obciążenia podatkowe ludności. Obok dotychczas jedynego podatku od dochodów wprowadzono nowe daniny, m.in. miejskie, gminne, od spadków i tzw. kominowe. Opodatkowano też produkcję soli i mąki. Surowa polityka fiskalna władz centralnych wobec Południa doprowadziła wkrótce do wzrostu cen wielu towarów, w tym podstawowych artykułów spożywczych - chleba i makaronów, co dotknęło szczególnie najbiedniejsze grupy społeczne. Towary pochodzące z Południa stawały się coraz mniej konkurencyjne na rynkach zagranicznych, co spowodowało drastyczne obniżenie eksportu i w konsekwencji załamanie się produkcji, zwłaszcza w branży spożywczej i tekstylnej. Sytuacja gospodarcza Południa ciągle się pogarszała również za sprawą całkowitego braku nowych inwestycji infrastrukturalnych (zwłaszcza drogowych), których niedostatek notowano jeszcze za panowania Burbonów (Janek, 2018). Wynikało to z faktu, iż gospodarka i wymiana handlowa Południa były silnie związane z transportem wodnym, który sprzyjał rozwojowi kluczowych w tamtym okresie portów morskich (Amalfi, Torre Annunziata, Neapol, Bari). De facto obszar byłego Królestwa Obojga Sycylii był traktowany przez władze centralne jak kolonia.

Na Południu obserwuje się w tym czasie nie tylko załamanie gospodarcze i brak spełnienia wspomnianych obietnic. Wprowadzono także nowe zasad prawne (obowiązkowy pobór do wojska młodych mężczyzn, głównie ze wsi, czego efektem był znaczący ubytek siły roboczej w gospodarstwach chłopskich) i administracyjnych (władze lokalne zastępowano, pod pretekstem walki z korupcją i klientelizmem, urzędnikami z Północy, co rodziło nieporozumienia i wzajemną niechęć). Janek (2018) zauważa, że na początku lat 60. XIX wieku na Południu panował chaos związany z antyburbońską rewoltą i upadkiem rządów Franciszka II, załamaniem gospodarki, pogorszeniem się warunków bytowych ludności oraz słabością, a niekiedy nieobecnością struktur nowego państwa. Wkrótce po zjednoczeniu, z jednej strony wzrosła aktywność grup przestępczych, a z drugiej na Południu powstali tzw. bryganci, czyli grupy sprzeciwiające się polityce sabaudzkiej i domagające się przywrócenia władzy dynastii Burbonów (brigantaggio). To przeciwko tym drugim (a nie mafii) państwo włoskie w 1863 roku wprowadziło rygorystyczne prawo Pica, umożliwiające egzekucje nawet w przypadku 
podejrzenia o niewierność wobec nowej władzy. Błędnym jest traktowanie fenomenu brigantaggio jako jednej z form działalności mafii, co w literaturze pojawia się dość często.

Działalność mafii w tym czasie rozszerzyła się ze względu na fakt, iż znaczna część urzędników i funkcjonariuszy na terenach Południa pochodziła z Północy. Ci natomiast nie znaleźli wsparcia wśród tamtejszych elit, które coraz chętniej wybierały efektywniejszą dla ich interesów ochronę zorganizowanych grup przestępczych. W takich warunkach władza centralna, nieposiadająca wystarczających środków i niedająca rzeczywistego poczucia bezpieczeństwa, została wyparta przez zorganizowane grupy przestępcze, które z sukcesem pacyfikowały państwowe interwencje przeciwko mafii. $\mathrm{Na}$ terytoriach kontrolowanych przez mafię dbano o to, aby skutecznie zwalczać również inne, pospolite formy przestępczości, przez co organizacja ta zyskiwała przychylność lokalnych społeczności. Ponadto fizyczna obecność mafii była o wiele bardziej skuteczna aniżeli formalna, jaką oferował rząd Piemontu, dlatego wzmocnienie pozycji tej pierwszej miało zdecydowanie większe powodzenie. Ponadto „w społecznym odbiorze wytworzył się fałszywy, funkcjonujący jeszcze przez wiele lat stereotyp dobrej mafii i złego państwa, następowała swoista legitymizacja i instytucjonalizacja mafii jako alternatywnej władzy" (Janek, 2018: 127-128 za Commissione Parlamentare AntimafiaLegislatura VI: 96).

Jednak takie działania dawały tylko pozorną ochronę i w żadnym stopniu nie faworyzowały rozwoju gospodarczego tej części kraju. Przykładem tego jest sytuacja, jaka panowała na Sycylii w latach 1891-1894, kiedy działały tam tzw. fasci dei lavoratori, czyli lokalne bractwa robotnicze na wzór związków robotniczych. Ich demonstracje przeciwko warunkom pracy były krwawo tłumione przez policję, wojsko, a także przez gabellotti ${ }^{1}$. Przemoc, której dopuszczali się lokalni mafiosi wobec podlegających im rolników, nie spotkała się z żadną reakcją władz sądowniczych. Wbrew sycylijskim fasciom państwo i mafia wydają się po raz pierwszy połączyć siły, aby utrzymać status quo. Sycylijscy robotnicy mieli bowiem pozostać w biedzie, analfabetyzmie, a ich byt miał zależeć od polityki gabellotti. Diametralne zmiany dla dalszego rozwoju organizacji kryminalnych w południowej części Królestwa Włoch przynióśł początek rządów faszystowskich. Dotychczas mafia miała możliwość rozwoju i kontroli terytorium pod nikłą i sporadyczną obecnością władzy państwowej. Natomiast celem faszyzmu było utworzenie państwa totalitarnego, kontrolującego każdy aspekt życia publicznego i prywatnego swoich obywateli, dlatego władza nie mogła zaakceptować (przynajmniej w teorii) obecności mafii.

Sytuacja utrzymująca się na Południu przez tak długi okres spowodowała drastyczne zwiększenie się dysproporcji w rozwoju społeczno-ekonomicznym pomiędzy tym a Północą, gdzie strategiczne w ówczesnym czasie gałęzie przemysłu znalazły wsparcie ze strony państwa. Konsekwencją takich działań była rekordowa przewaga w poziomie industrializacji regionów północno-zachodnich Włoch w stosunku do pozostałej części

${ }^{1}$ Gabellotto - określenie to stosowano do osób dzierżawiących duże posiadłości ziemskie (gabelle) na obszarze Sycylii i Kalabrii w XIX wieku i w pierwszej połowie XX wieku. Figura ta odróżniała się od właścicieli ziemskich tym, że ten drugi zwykle należał do stanu szlacheckiego, natomiast gabellotti to drobna rolnicza burżuazja, która wykorzystując niezdolność klasy szlacheckiej do zarządzania posiadłościami ziemskimi, przejmowała od nich prawo do zarządzania lennem. 
kraju. Dlatego we Włoszech z czasem wykształciły się trzy wyraźnie odrębne obszary: (1) północno-zachodni, (2) północno-wschodni i centrum oraz (3) Południe i wyspy.

Według szacunków w 1951 roku najbogatszym regionem Włoch była Liguria, kolejno Lombardia i Piemont. Taka konfiguracja wynika z faktu, że w Ligurii oprócz przemysłu silnie prosperował sektor usług (finanse, transport i komunikacja), który wspiera rozwój trójkąta przemysłowego. Jednak po 1961 roku region ten odnotował największy spadek wielkości PKB, a w kolejnych dziesięcioleciach tendencja spadkowa jeszcze bardziej się nasiliła, przez co Liguria znalazła się poniżej średniej poziomu wzrostu dla obszaru północno-zachodniego (odpowiednio 116,2\% w stosunku do prawie 128\%), a w ostatnim dwudziestoleciu została wyprzedzona przez Emilię Romanię i Toskanię. Model rozwoju Ligurii wyjaśnia przyczyny wzrostu, a następnie znacznego spowolnienia gospodarczego regionu. Przemysł liguryjski swoje powstanie i dalszy rozwój w znacznym stopniu zawdzięcza interwencji publicznej. W XIX wieku szereg ustaw protekcjonistycznych przewidywało zamówienia i finansowanie według sektorów, spośród których do najważniejszych należały przemysł stoczniowy, mechanika ciężka i przemysł stalowy. Trzy czwarte środków, jakie przeznaczyło państwo na ten cel, zostało skierowane właśnie do Ligurii. W tym samym czasie rozwinął się transport morski w Genui i mniejszych portach regionu (La Spezia, Savona). Ponadto, to głównie liguryjskie giganty stali i mechaniki: Ilva i Ansaldo, uzyskują największe finansowanie po pierwszej wojnie światowej (Noviello, 2018). Dlatego model liguryjski łączy ze sobą elementy przedsiębiorczości prywatnych inwestorów z ogromną dozą pomocy publicznej. Tego rodzaju kapitalizm okazuje się mniej konkurencyjny i łatwiej wchodzi w kryzys, zwłaszcza w czasie, gdy środki publiczne w okresie boomu gospodarczego zostają skierowane na Południe. Czas ten był szansą dla liguryjskich inwestorów na rozwój innowacyjności, co jednak nie miało miejsca. W obliczu upadku przemysłu, region wykazuje wczesną zdolność do rekonwersji w usługi przez relokację przemysłu do pobliskiego Piemontu na rzecz rozwoju turystyki. Dzięki temu od początku lat 80. XX wieku w Ligurii notuje się wzrost inwestycji w sektor usług (choć jest to cechą wspólną wszystkich dobrze rozwiniętych gospodarek), to w regionie tym udział pracujących w usługach pozostaje wyższy nawet o 15-20\% w stosunku do Lombardii czy Piemontu. Z tego względu Liguria jest przykładem regionu, który w stosunkowo krótkim czasie przeszedł ścieżkę historycznej ewolucji od regionu silnie uprzemysłowionego do dominującego w sektorze usługowym. Dlatego mimo spadku wielkości PKB per capita, region posiada prymat w indeksie rozwoju społecznego (HDI), będącym wypadkową wielkości dochodu per capita, średniej długości życia oraz wskaźnika wykształcenia.

Obok dobrze prosperującej Ligurii, do dzisiaj prężny rozwój gospodarczy charakteryzuje region Lombardii, która począwszy od lat 50. XX wieku wykazuje najwyższy wskaźnik PKB per capita (poza niewielkim regionem Doliny Aosty utrzymującym się z rozwoju turystyki i ostatnio również Trydentem-Górną Adygą). W przeciwieństwie do Ligurii, Lombardia prezentuje ciągły systematyczny rozwój przemysłu, który następuje zasadniczo bez pomocy państwa (lub z jego niewielkim udziałem). Sukcesem regionu był rozwój elektrowni wodnej (pierwszej w Europie), dzięki której powstała firma Edison - jedno z największych przedsiębiorstw przemysłowych w kraju. W regionie powstawały coraz liczniejsze struktury finansowe opierające się na dużych mediolańskich bankach, Włoskim Banku Komercyjnym (Comit) i Włoskim Kredycie (Credit). Nie brakowało mniejszych instytucji jak kasy oszczędnościowe czy banki spółdzielcze. W takim ujęciu kapitalizm wielkich przedsiębiorstw integruje się z kapitalizmem 
okręgów przemysłowych znacznie lepiej niż w jakimkolwiek innym regionie kraju. To dzięki temu przenikaniu się, kiedy w latach 70. XX wieku model fordystyczny, oparty na wielkim kapitałochłonnym przedsiębiorstwie, popada w kryzys, Lombardii udaje się utrzymać pozycję lidera. Na tym etapie następuje ważne przejście: od dużego kombinatu do struktury przedsiębiorstw średnich, silnie zorientowanych na eksport (Candy, MIVAR). Lombardię wyróżnia wysokie PKB, które znajduje odzwierciedlenie w bardzo wysokich wskaźnikach aktywności w przemyśle i poziomie produktywności. Przemysł zapewnia zatrudnienie dla około 40\% ludności regionu (Felice, 2010). Ponadto sektor ten jest w dużym stopniu obsługiwany przez usługi przynoszące znaczne dochody, co zwiększa produktywność regionu.

Innym dobrze prosperującym regionem jest Piemont, gdzie poza znaczną pomocną finansową ze strony państwa, decydujące było sąsiedztwo Ligurii i Lombardii. Dlatego rozwój gospodarczy regionu można uznać za hybrydowy, gdyż łączy model liguryjski z lombardzkim, a doskonałym przykładem tego jest powstała przed pierwszą wojną światową fabryka Fiata. Dzięki wsparciu państwa już na początku XX wieku stała się ona liderem w produkcji samochodów, a jej sytuacja stale się poprawiała, najpierw w okresie pierwszej wojny dzięki zamówieniom ze strony państwa, następnie dzięki wdrożeniu planu Marshalla (restrukturyzacja przedsiębiorstw, masowa produkcja) i kolejno pomoc z Kasy Południa (Cassa per il Mezzogiorno) w celu rozszerzenia produkcji na Południu (Pomigliano d’Arco koło Neapolu). Fiat dzięki szerokiej ofercie i stosunkowo niskiej cenie samochodów wskazuje, że jest firmą, która potrafi konkurować na rynkach międzynarodowych (Amatori, Colli, 1999; Felice, 2010). W Piemoncie podobnie jak w Lombardii dużą rolę odegrały duże banki i inne struktury kredytowo-finansowe. Ponadto dokonana w Italii na początku XX wieku nacjonalizacja kolei i komunikacji tramwajowej, a następnie wprowadzenie innowacyjnych rozwiązań pozwoliło na zwiększenie popytu na półprodukty przemysłu mechanicznego, które wytwarzano w fabrykach piemonckich. Rozwój przemysłu dokonał się również w mniejszych ośrodkach (Biella - sektor tekstylno-wełniany, Novara - armatura sanitarna, Valenza - złotnictwo). Wysoka, ale nieporównywalna z Lombardią, pozycja Piemontu determinowana była stosunkowo wysokim udziałem pracujących w rolnictwie (większym aniżeli w Lombardii) i wynikającym z tego niższym udziałem zatrudnionych w usługach.

Rozwój gospodarczy regionów północno-wschodnich i centralnych rozpoczął się już w pierwszej połowie XX wieku, a dotyczy to zwłaszcza Emilii-Romanii (przemysł mechaniczny) i regionów z nią graniczących (Toskania, Marche, Wenecja Euganejska), gdzie rozwinął się przemysł lekki (tekstylia, odzież, żywność) w symbiozie z działalnością rolniczą. W procesie tym brakowało jednak odpowiedniego jak na ten czas poziomu technologii (Felice, 2007). W okresie międzywojennym nadal rozwija się przemysł mechaniczny, a niszowy przemysł samochodowy zyskuje na znaczeniu i ma szansę na dalszy rozwój podobnie jak miało to miejsce w przypadku Maserati i Ferrari w prowincji Modena oraz Lamborghini w prowincji Ferrara (Felice, 2010). W okresie międzywojennym wartości PKB na mieszkańca w regionach centralnych rosną mniej niż w tych północnych, utrzymując średnią krajową, ale będących bliżej wartości uzyskanych na Południu (różnica 43 punktów in plus) aniżeli tych na północnym zachodzie (różnica 49 punktów in minus). Północno-wschodnia i centralna część kraju w drugiej połowie XX wieku przeszła okres wielkiej konwergencji, zbliżając się do poziomu rozwoju północno-zachodniej części Italii. Stało się tak za sprawą wzrostu produkcji w przemysłach 
(od tekstyliów i odzieży, przez mechanikę lekką, po ceramikę), których produkcja koncentrowała się w obrębie małych przedsiębiorstw, często skupionych geograficznie.

Ponadto w latach cudu gospodarczego we Włoszech i za granicą panował wspomniany paradygmat fordystyczny, skupiający się na dużych firmach w sektorach zaawansowanych technologicznie, to znaczy raczej kapitałochłonnych niż pracochłonnych. Pod wpływem tego paradygmatu działalność na obszarach graniczących z trójkątem przemysłowym była postrzegana jako marginalna lub co najwyżej komplementarna do rdzenia, czyli wielkiego przemysłu północno-zachodnich Włoch. Przyjęło się argumentować, że Wenecja Euganejska, Emilia-Romania, Marche i Toskania postawiły na sektory produkcyjne, które nie odpowiadały wielkościowo przedsiębiorstwom fordowskim. Były to bowiem małe zakłady produkcyjne, które działały jako dostawcy i podwykonawcy dużych firm.

Kryzys naftowy spowodował znaczne spowolnienie gospodarcze w całej Europie, natomiast w samych Włoszech notuje się duże zróżnicowanie regionalne pod tym względem. Regiony Południa notują zahamowanie, na północnym zachodzie nastąpiło znaczne spowolnienie gospodarcze, natomiast północny wschód staje się nowym centrum rozwoju gospodarczego kraju. Wtedy też pojawia się po raz pierwszy określenie „trzecia Italia” (terza Italia) wyodrębniona w 1977 roku przez Arnaldo Bagnasco. Autor do trzeciej Italii zalicza: Trójwenecję (Trydent-Górna Adyga, Wenecja Euganejska i Friuli-Wenecja Julijska), tzw. regiony czerwone (Emilia Romania, Toskania i Umbria) oraz Marche. Z podziału przedstawionego przez Bagnasco zostaje wyłączone Lacjum, które ze względu na ulokowaną tam stolicę kraju, nie wpisuje się do żadnej z trzech Italii. Region ten już kilka lat po zjednoczeniu kraju silnie ugruntował swój rozwój inwestując w najbardziej opłacalny sektor gospodarki jakim były usługi. Felice (2010) stwierdza, że gdyby nie stołeczna rola regionu, Lacjum zostałoby wpisane na listę zdecydowanie słabiej rozwijających się regionów Mezzogiorno. Trzecia Italia Bagnasco to obszar, który charakteryzuje się specyficzną morfologią (i związanym z nią rozwarstwieniem społecznym) skoncentrowaną na małych przedsiębiorstwach, które czynią ten obszar zasadniczo odmiennym od północno-zachodniego. Bagnasco na obszarze trzeciej Italii zauważa również historyczne różnice w funkcjonowaniu produkcyjnej tkanki społecznej i towarzyszącej jej infrastruktury. Odmienność organizacji produkcji jest wynikiem odmiennej struktury agrarnej, która istniała tam przed epoką przemysłową (rozdrobnienie użytków rolnych). Liczne rodziny farmerów stanowiły pewnego rodzaju inkubator dla rozwoju gospodarki tej części Włoch, podczas gdy infrastruktura jest ukierunkowana na budowanie sieci i relacji poziomych, wzrost roli instytucji lokalnych w stosunku do odgórnych procesów decyzyjnych, podkreślając integralność tego obszaru.

Jak zauważa Putnam (1993) kilka lat po badaniach Bagnasco, w 1979 roku inny włoski badacz - Giacomo Becattini - opisując zmiany w krajobrazie (mnogość winnic) tej części Włoch określa ją jako bogatą w obiekty przemysłowe silnie wyspecjalizowane i ukierunkowane na eksport, silnie powiązane z lokalnymi instytucjami i infrastrukturą, korzystające z wysokiego kapitału społecznego. Polityka regionalna, bo taka od kilku dekad charakteryzuje północne i środkowe Włochy (po Abruzję) oparta jest na funkcjonowaniu przedsiębiorstw przemysłowych silnie zintegrowanych w ramach regionalnych społeczności, co stanowi o sile tych terytoriów. Od początku lat 90. XX wieku obraz uprzemysłowienia włoskich regionów zmienia się właśnie za sprawą rozwoju małych i średnich przedsiębiorstw. W ostatnich dziesięcioleciach na skutek 
wprowadzenia euro, model przedsiębiorstw ulega zmianie. Niektóre z nich zyskują na sile i konkurując na rynkach międzynarodowych. Podporządkowują one sobie mniejsze przedsiębiorstwa stając się średniej wielkości przedsiębiorstwami międzynarodowymi. 0 sukcesie małych i średnich przedsiębiorstw północnych i środkowych Włoch zadecydowały również inicjatywy w sektorze usług biznesowych, zainicjonowane w latach 70. i 80. XX wieku. Działania te obejmowały organizację szkoleń i targów ${ }^{2}$, wsparcie finansowe, prowadzenie działalności badawczo-rozwojowej. Działaniom tym towarzyszy wsparcie instytucji regionalnych oraz ich działania, na co zwraca uwagę Putnam (1993), przywołując przykład regionu Emilia-Romania, gdzie efektywność instytucji publicznych determinuje wysoki poziom kapitału społecznego.

Dużo gorsza sytuacja panowała na Południu. W okresie od zjednoczenia kraju do początku drugiej wojny światowej pozycja Mezzogiorno uległa pogorszeniu, a wyraźne załamanie dotyczy okresu międzywojennego. Zmniejszały się również dysproporcje w rozwoju gospodarczym regionów Południa, ale zmiany te oznaczały osłabienie pozycji regionów uprzednio najsilniejszych (Kampania, Sycylia), które przed zjednoczeniem kraju stanowiły centra życia społecznego i prężnie rozwijającej się działalności usługowej i produkcyjnej. Działalność rolnicza Apulii (produkcja wina i oliwy) oraz Sycylii (owoce cytrusowe i ich pochodne) znana również za granicą, stanowiła o sile i potencjale gospodarczym regionów Południa. Jednak z upływem lat i na skutek nieefektywnej polityki industrializacyjnej opracowanej dla regionu Kampania (Noviello, 2018) oraz polityki faszystowskiej, gospodarka regionów Mezzogiorno stopniowo traciła na znaczeniu. Państwo faworyzowało uprzemysłowienie Północy, odkładając w czasie zabiegi związane chociażby z przekształceniem struktury agrarnej. Takie działania spowodowały, że w pierwszej połowie XX wieku na Południu nie tylko brakowało inwestycji w przemysł, ale zatrudnienie w rolnictwie pozostawało na niezmienionym poziomie $60 \%$. Ponadto odnotowano znaczny spadek produktywności w przeliczeniu na jednego zatrudnionego $\mathrm{w}$ rolnictwie.

Taki układ sił i wpływ poszczególnych sektorów gospodarki na rzecz poprawy sytuacji gospodarczej Włoch po drugiej wojnie światowej spowodował, że Południe stało się obszarem, gdzie zastosowanie narzędzi interwencjonizmu państwowego stało się zabiegiem koniecznym.

\section{WYBRANE PROGRAMY I DZIAŁANIA NA RZECZ POPRAWY SYTUACJI GOSPODARCZEJ POŁUDNIA}

Na początku XX wieku sytuacja społeczno-ekonomiczna na południu Włoch była bardzo niekorzystna, o czym świadczy m.in. masowy, nigdy wcześniej nienotowany odpływ ludności najpierw na Północ i do krajów Europy Zachodniej, a w kolejnych latach również za ocean (Noviello, 2018, 2021; Pelaggi, 2016). To niepokojące zjawisko zmusiło niejako rządy sabaudzkie do podjęcia konkretnych starań na rzecz realnej poprawy sytuacji gospodarczej na Południu. W kolejnych dziesięcioleciach nie tylko rząd, ale i utworzone z jego inicjatywy instytucje i ośrodki naukowe dążyły do opracowania koncepcji rozwoju pozwalających na poprawę kondycji strategicznych sektorów gospodarki, ale i rozbudowę infrastruktury i zapewnienie odpowiednich zasobów ludzkich, które

${ }^{2}$ Pierwsze takie targi odbyły się w Bolonii w 1888 roku i stały się corocznym wydarzeniem cyklicznym o międzynarodowej randze. 
miały w kolejnych okresach stanowić o sile gospodarczej regionów. W pracy przedstawiono wybrane instytucje, działania czy programy, które miały wpływ na dalsze losy gospodarki Południa:

1. Plan rozwoju dla Południa (1904) - pierwszym dużym przedsięwzięciem było opracowanie koncepcji uprzemysłowienia regionów Południa znanej w literaturze jako Plan Rozwoju dla Południa (Piano di sviluppo per il Mezzogiorno). Plan zakładał nie tylko rozwój przemysłu chemicznego, ale również budowę dużego kombinatu hutniczego w Neapolu (dzielnica Bagnoli). Huta stali Ilva, w której produkcję stali rozpoczęto w 1910 roku, już w kolejnym roku jej prężnej działalności odnotowano kolosalny wzrost wartości dodanej brutto plasując region na czwartej pozycji w skali kraju (po Toskanii, Ligurii i Lombardii). Zatem można by mówić o wielkim sukcesie w realizacji założeń tego planu, ale - jak pokazały doświadczenia kolejnych dziesięcioleci - i ostateczne zamknięcie zakładów na początku lat 90. XX wieku oraz problemy społeczne i ekologiczne z tym związane, trudno jest z perspektywy czasu ocenić realizowany plan jako korzystny dla realnego rozwoju Południa (Noviello, 2018).

2. Plan Sinigaglia (1948) - plan ten zakładał rekonstrukcję i modernizację branży hutniczej, która bardzo mocno ucierpiała po drugiej wojnie światowej (zniszczenia zakładów w Cornigliano, Piombino i zatrzymanie produkcji stali w Bagnoli) (Noviello, 2018). Realizacja tych działań stała się możliwa dzięki uzyskanemu kredytowi w wysokości 15 mld lirów w ramach planu Marshalla. Pozwoliło to m.in. na dynamiczny wzrost produkcji stali (z 2,2 mln ton w 1948 roku do 4,2 mln ton w roku 1954), który wynikał ze wzrostu wydajności i spadku kosztów wytwarzania. Zaobserwowano także spadek liczby zatrudnionych w hutnictwie (o prawie 8 tys. osób), co wynikało z przeprowadzonej restrukturyzacji (Janek, 2016; Sinigaglia, 1948).

3. Centrum Studiów nad Rozwojem Gospodarczym Południa SVIMEZ ${ }^{3}$ (1946) - to pierwsza taka inicjatywa państwowa mająca na celu nie tylko badanie problemów związanych z rozwojem społeczno-gospodarczym Południa, ale i partycypacji ośrodka na rzecz rozwoju gospodarczego Południa. Partycypacja ta polegała zarówno na badaniu zróżnicowania społeczno-ekonomicznego i problemów z tym związanych, jak również na ocenie skuteczności i zasadności dokonanych przez państwo działań. Wyliczono m.in., że środki wydatkowane z Kasy Południa w znacznie większym stopniu zasiliły budżety przedsiębiorstw zlokalizowanych na Północy, co było spowodowane importem znacznej części surowców i towarów w celu realizacji zadań publicznych na Południu. SVIMEZ oprócz wspomnianych badań jest odpowiedzialny za przygotowanie i opracowanie danych ekonomicznych stanowiących punkt wyjścia dla planów państwowych (Czuma, 1969).

4. Kasa Południa - Cassa per il Mezzogiorno (1950) - to jedyna na tak dużą skalę instytucja kredytująca działalność rozwojową Południa (Czuma, 1969). Wydatki w ramach środków dostępnych z Kasy miały pokryć głównie rozbudowę infrastruktury, utworzenie korzystnych warunków dla prywatnych inwestorów, wsparcie bezpośrednimi inwestycjami państwa w zakresie chociażby wprowadzenia innowacyjności w przemyśle, jego intensyfikację i przede wszystkim restrukturyzację

${ }^{3}$ Nazwa tego ośrodka jest skrótem pochodzącym od Sviluppo Mezzogiorno oznaczającego rozwój Południa. 
rolnictwa. Założenia te formalnie sankcjonowała ustawa nr 634 z 1957 roku, z zapisów której wynika, że 40\% inwestycji produkcyjnych i 60\% wszystkich pozostałych inwestycji ma być lokowane na Południu. Bardzo silny nacisk kładziono na rozwój rolnictwa. Z tego względu w pierwszym okresie przypadającym na lata 1950-19654 największe wydatki Kasa poniosła na rzecz rolnictwa (1244 mld lirów), co stanowiło ponad 50\% całkowitych wydatków. W dużym stopniu finansowano również budowę i rozbudowę infrastruktury (prawie 500 mld lirów), ale jak już wspomniano największym beneficjentem tych środków były regiony północne. W pierwszym okresie wydatkowania marginalnie potraktowano nie tylko turystykę (4,2\% wydatków), ale przede wszystkim przemysł (6,9\% wydatków), w którym Włochy w okresie boomu gospodarczego lat 50. i 60. XX wieku mogły mieć nadzieję na niwelowanie różnic w poziomie rozwoju gospodarczego. Dopiero w drugim, znacznie krótszym okresie wydatkowania przypadającym na lata 19651969, rząd włoski zwiększył środki na rozwój przemysłu (do 750 mld lirów, co stanowiło nieco ponad 44\% wszystkich wydatków z tego okresu), ale nie był to tak pokaźny zastrzyk finansowy jak miało to miejsce w pierwszym okresie w przypadku pomocy dla znacznie mniej dochodowego rolnictwa. Wydatkowanie w pierwszym okresie w pewnym stopniu okazuje się zasadne, gdyż w ocenie Czumy (1969) dużą część środków przeznaczono na rozwój infrastruktury i szkolenie kadry, bez których przemysł nie może efektywnie funkcjonować. Ponadto w dziedzinie rolnictwa Kasa dokonała znacznego podziału wielkich gospodarstw rolnych, które nie mogły już konkurować z dobrze prosperującymi i wielkopowierzchniowymi gospodarstwami północnej części kraju. Dlatego w warunkach silnej konkurencji (również zagranicznej) gospodarstwa rolne Południa miały nikłe szanse na dynamiczny rozwój. Ze środków Kasy Południa korzystały m.in. konsorcja, czyli ośrodki władz lokalnych odpowiedzialne za wskazanie i finansowanie ośrodków czy obszarów intensywnej industrializacji. Ponadto do ich zadań należało tworzenie planów rozwojowych i współpracy z prywatnymi inwestorami. Te rozwinęły swoją działalność dopiero w drugim okresie finansowania ze środków Kasy Południa (Czuma, 1969). Środki pochodzące z Kasy miały również służyć tworzeniu na południu kraju obszarów rozwoju przemysłu zlokalizowanych wokół dużych ośrodków miejskich (powyżej 200 tys. mieszkańców). Wiele z tych ogniw, mimo że z założenia miało angażować znaczny potencjał społeczny regionów, istniało jedynie formalnie, generując koszty i marnotrawiąc środki z Kasy Południa. Mimo tych działań okazuje się, że jednym z największych problemów odnośnie do wydatkowania środków z Kasy Południa było niedostosowanie skali przedsięwzięć państwowych do lokalnych warunków społeczno-ekonomicznych i infrastrukturalnych. Za największe błędy w tym względzie uznano lokowanie dużych zakładów, jak rafinerie w Gela i Cagliari, huty w Taranto czy zakładów chemicznych w Brindisi. Okazuje się bowiem, że te nie tylko generowały ogromne nakłady kapitałowe w przeliczeniu na jednego mieszkańca, ale nie były w stanie ograniczyć bezrobocia do pożądanego stopnia. Zakłady wymagały bowiem wykwalifikowanej siły roboczej, której należało szukać w centralnej i północnej części kraju. Ponadto w związku z tym, że zakłady te specjalizowały się w produkcji półproduktów wysyłanych dalej na Północ, nie tworzyły korzystnych warunków dla rozwoju innych

\footnotetext{
${ }^{4}$ Pierwszy, piętnastoletni okres finansowania zamykał się 30.06.1965 r.
} 
przedsiębiorstw czy usług (Janek, 2016). W wydatkowaniu środków z Kasy Południa można zauważyć liczne mankamenty inwestycyjne: m.in. to, że infrastruktura była budowana niejako na wyrost, bez konkretnego planu rozwoju poszczególnych obszarów, co oznaczało nie tylko niewłaściwe lokowanie środków, ale generowało późniejsze wydatki na utrzymanie funkcjonalności tej infrastruktury. Natomiast biorąc pod uwagę rachunek ekonomiczny, to skuteczność dokonanych przedsięwzięć w zakresie chociażby budowy infrastruktury czy przyciągania kapitału prywatnego była niewspółmiernie niska. W takiej sytuacji, jak zaznacza Janek: „decydująca okazała się logika rachunku ekonomicznego (...) - mimo ulg, inwestowanie na zacofanym, biednym, pozbawionym infrastruktury Południu było znacznie kosztowniejsze i bardziej ryzykowne, a realna stopa zwrotu kapitału niższa niż w pozostałych, lepiej rozwiniętych regionach. W tych warunkach liczący się włoscy przedsiębiorcy byli bardziej zainteresowani ekspansją zewnętrzną niż podejmowaniem ryzyka na Południu. Region ten omijał również kapitał zagraniczny, koncentrując swoje przedsięwzięcia głównie na północy Włoch" (Janek, 2016: 159). Kasa Południa funkcjonowała do 1986 roku, po czym została zastąpiona przez agencję „Agensud”, która została rozwiązana w 1992 roku, nieprzynosząc wyraźnych efektów dla rozwoju gospodarczego Południa. Podjęte w tym czasie inwestycje okazały się nieefektywne, gdyż oparte były na nieracjonalnych oczekiwaniach dotyczących popytu (centrum stalowe w Gioia Tauro na pn. od Reggio di Calabria) lub na podstawie kryteriów wykraczających poza wszelką racjonalność ekonomiczną (zakład petrochemiczny w Ottanie w centrum Sardynii!). U źródeł obu interwencji leżały powody polityczne. W kolejnych latach inwestycje stały się również okazją do ingerencji organizacji przestępczych, które zmniejszyły szanse powodzenia polityki regionalnej i ponownego ożywienia gospodarczego. Stało się tak również za sprawą wielkiego marnotrawstwa zasobów finansowych na rzecz działających sił politycznych.

5. Instytucje kredytowe - do tej grupy instytucji gotowych wspomagać rozwój obszarów zacofanych gospodarczo należały wówczas Bank Neapolitański, kasy oszczędnościowe, banki ludowe, ale również powstałe w latach 50. XX wieku trzy regionalne instytucje: ISVEIMER (Istituto per lo Sviluppo Economico dell'Italia Meridionale) działający w południowej części półwyspu, IRFIS (Istituto Regionale per il Finanziamento alle Industrie in Sicilia) z siedzibą w Palermo oraz CIS (Credito Industriale Sardo) zlokalizowana na Sardynii. Możliwości finansowania działalności gospodarczej były dostępne zarówno na Północy, jak i Południu, gdzie warunki kredytobiorcze były bardziej korzystne aniżeli w regionach północnych: wielkość kredytu do 70\% stałych kosztów inwestycyjnych, oprocentowanie 3\% (na Północy 5\%), długoterminowość - do 15 lat (na Północy do 10 lat), możliwość anulacji kredytu, a kredyty przemysłowe do 1 mld lirów (na Północy do 500 tys. lirów). Jednak mimo tak korzystnych warunków kredytowych znacznie większa ilość nowych przedsiębiorców preferowała rozpoczęcie działalności w północnej części kraju.

6. Plan Vanoniego (1955), czyli „Dziesięcioletni plan rozwoju dochodów i zatrudnienia we Włoszech w latach 1955-1964". Teoretyczna podbudowa planu odnosiła się do keynezowskich doktryn ekonomicznych (utrzymanie pełnego zatrudnienia, zwiększenie wydatków budżetowych na rozwój inwestycji publicznych, wzrost znaczenia roli państwa w gospodarce). Plan miał za zadanie określenie głównych kierunków rozwojowych oraz zwiększenie skuteczności polityki społecznej 
poprzez bardziej sprawiedliwy podział dochodu narodowego (Janek, 2016). Jednym z podstawowych zadań, jakie stało przed państwem było zmniejszenie dysproporcji w rozwoju na linii Północ-Południe. Cel ten miał być realizowany na Południu przez zwiększenie zatrudnienia $w$ rolnictwie, $w$ instytucjach publicznych czy przy realizacji dużych inwestycji infrastruktury technicznej użytku publicznego (mosty, drogi). Środki przeznaczone na realizację tego planu stanowiły dość pokaźne sumy (ponad 24 tys. mld lirów, czyli około 39 mld USD), z czego ustalono, że na obszarze Mezzogiorno z tej puli należy zrealizować $54 \%$ inwestycji w rolnictwo, $36 \% \mathrm{w}$ zakresie usług publicznych, $48 \% \mathrm{w}$ budownictwie mieszkaniowym i $50 \%$ realizując zadania dotyczące robót publicznych. W związku z tym, że już w pierwszych latach wdrożenia planu prognozy głównych wskaźników makroekonomicznych były znacznie zaniżone w stosunku do realnej sytuacji na rynku, to po trzech latach od jego wdrożenia, odstąpiono od realizacji założeń planu, gdyż wypełnienie poszczególnych postulatów stanowczo ograniczałoby wzrost gospodarczy kraju. Również założenia planu, w tym bardzo silny akcent na rozwój gałęzi przemysłu ciężkiego, małe zaangażowanie w implementację przemysłu motoryzacyjnego czy chemicznego oraz niedostateczny rozwój infrastruktury drogowej spowodowało, że dla gospodarki Południa nie był on instrumentem, które w rozległym horyzoncie czasowym można by uznać jako to, które przyczyniło się do niwelacji różnic w poziomie rozwoju między Północą a Południem.

7. Ministerstwo Udziałów Państwowych - Ministero delle Partecipazioni Statali (1956) - organ państwowy utworzony w celu zmniejszania różnic w rozwoju gospodarczym między północną a południową częścią kraju m.in. poprzez opracowywanie i wdrażanie programów i strategii inwestycyjnych na obszarach zacofanych gospodarczo. Tam też we wspomnianych dokumentach silnie akcentowano rozwój inwestycji publicznych, infrastruktury, która pozwoli na połączenie obszarów słabiej rozwiniętych z tymi dobrze prosperującymi. Efektem tego było nadanie przez Ministerstwo wyłącznej koncesji dla Instytutu Rekonstrukcji Przemysłu ${ }^{5}$ (Istituto per la Ricostruzione Industriale, IRI) na budowę autostrad, których sieć miała zostać wzbogacona o ponad 3 tys. km łącząc przy tym wszystkie regiony kraju. Efektem działań kierowanych przez IRI była budowa autostrady Słońca (Autostrada del Sole) stanowiącej symbol nawiązania realnej współpracy i wzajemnego otwarcia rynków bogatej Północy i biednego Południa. Jej wymiar społeczny był jeszcze większy, gdyż po raz pierwszy w tak znacznym stopniu i na tak dużą skalę możliwa była wymiana kapitału społecznego, choć dla Południa oznaczało to jego utratę na rzecz stopniowo bogacącej się Północy.

\section{OCENA WPŁYWU INTERWENCJI PAŃSTWOWYCH NA WSPÓŁCZESNE MOŻLIWOŚCI ROZWOJU GOSPODARCZEGO WŁOSKICH REGIONÓW}

Zaobserwowane skutki realizowanych działań na rzecz rozwoju Południa wskazują niejednokrotnie na wzrost dysproporcji i nasilenie się negatywnych procesów (np. wzrost emigracji) na tych obszarach Włoch, co może oznaczać, że wiele interwencji rządowych na rzecz Południa, przyniosło więcej korzyści dla gospodarki regionów

${ }^{5}$ W skład IRI wchodziło kilka najważniejszych firm jak STET, Finmare, Finsider, Finmeccanica, Fincantieri i inne mniejsze spółki (zob. Janek, 2016: 164). 
zlokalizowanych na północy kraju. Wynika to z faktu, iż Południe na każdym etapie wdrażania planów inwestycyjnych pozostawało o kilka lat wstecz w stosunku do Północy, gdzie zwłaszcza gospodarka wolnorynkowa lat 60 . XX wieku i następnych silnie akcentowała nie tylko eksport, podejmowano ciągłe starania mające na celu poprawę wydajności produkcji, a przemiany społeczno-ekonomiczne i postęp techniczny spowodowały, że cały wewnętrzny rynek konsumpcyjny artykułów trwałego użytku silnie opierał się na produkcji w fabrykach na Północy. Ponadto nie można pominąć tego, $\mathrm{w}$ jakim zakresie zostały zrealizowane postulaty wspomnianej ustawy $\mathrm{nr} 634$. Okazuje się bowiem, że jedynie 25\% (a nie jak zakładała ustawa 40\%) wszystkich włoskich inwestycji brutto zostało zrealizowanych na Południu. Analogiczny wskaźnik dla przedsiębiorstw państwowych grupy IRI był wyższy i plasował się na poziomie nieco powyżej 33\%, czyli 389 mld lirów, a inwestycje zrealizowane na Południu (w skali kraju) obejmowały w największym stopniu: sektor energetyczny (56,8\%), transport lotniczy (38\%), transport morski (36\%), budowę autostrad (33,6\%), przemysł maszynkowy $(30,6 \%)$, telekomunikację $(20,1 \%)$, hutnictwo $(10 \%)$ oraz inne sektory o łącznym udziale na poziomie $27,1 \%$.

W przeprowadzonej interwencji państwa w rozwój Południa kwestionuje się również brak kompetencji w ocenie dostępnych zasobów ludzkich i walorów krajobrazowych, które w szczególny sposób wyróżniają południową część Włoch. Dlatego, jak stwierdza Fenoaltea (2007), inwestycje w rozwój infrastruktury drogowej i turystycznej w szerszej perspektywie czasowej byłyby o wiele bardziej produktywne na Południu. Takich działań jednak nie poczyniono, ale wręcz z uporem realizowano program industrializacji Południa, który ostatecznie zaowocował powstaniem 22 ośrodków przemysłowych i 15 obszarów przeznaczonych dla rozwoju przemysłu (Felice, 2007). W efekcie, kiedy na początku lat 90 . XX wieku na terytorium Włoch notowano spadek produkcji przemysłu ciężkiego, w znacznym stopniu dotknęło to wielkości PKB per capita wytwarzanego w dużych zindustrializowanych regionach na Południu (Kampania, Sycylia, Apulia, Kalabria). Natomiast w pozostałych regionach Mezzogiorno - mniejszych powierzchniowo i o mniejszej liczbie ludności (Molise, Abruzja, Bazylikata) - w okresie realizacji planu odbudowy Południa, podjęte inwestycje miały znacznie mniejszą skalę. Wynikało to $\mathrm{z}$ warunków orograficznych tych regionów oraz dużego rozproszenia ludności i małej gęstość zaludnienia, które znacznie ograniczały zasoby pracy dla wielkich przedsiębiorstw. W rejonie Pescary w Abruzji planowano budowę wielkiej rafinerii, jednak pod wpływem protestów mieszkańców regionu i propozycji nowych inwestycji fabryki Fiata, ta pierwsza nie została zrealizowana. Fiat natomiast korzystając ze środków Kasy Południa, zrealizował w Abruzji fabrykę Sevel, która obok pobliskiego Termoli (Molise) stanowiła jedną z większych sił napędowych gospodarki Abruzji i Molise. Ponadto w regionach mniej zaludnionych interwencje koncentrowały się na budowie infrastruktury drogowej i wodnej, przemyśle lekkim, a wsparcie znajdowały głównie małe przedsiębiorstwa (produkcja szkła, odzieży, elektroniki). Z tego względu przemysł, jaki rozwinął się $w$ tych regionach w znikomym stopniu ucierpiał na kryzysie naftowym lat 70. XX wieku. Obok Abruzji i Molise, regionem, który (choć znacznie wolniej) notuje wzrost gospodarczy, jest Bazylikata. W Melfi w 1993 roku powstaje kolejna fabryka Fiata przynosząc wielkie efekty mnożnikowe zwłaszcza w sektorze usług. Ponadto $\mathrm{w}$ regionie pojawiły się szyby naftowe, rozwinął się przemysł odzieżowy i meblarski, a aktualna sytuacja gospodarcza jest również zasługą polityki 
lokalnej i dobrze zorganizowanego społeczeństwa konsekwentnie walczącego ze zorganizowaną działalnością przestępczą.

Regionem, który w ciągu ostatnich czterdziestu lat notuje stopniowy wzrost gospodarczy jest Sardynia. Jej położenie oraz bardzo niekorzystna sytuacja gospodarcza spowodowały, że region był beneficjentem środków w ramach Kasy Południa. Na Sardynii rozwinął się przemysł chemiczny oraz turystyka (Costa Smeralda w okolicach Olbia na pn.-wsch. wybrzeżu), jednak wspomniany kryzys lat 70. XX wieku spowodował znaczne straty w sektorze przemysłu chemicznego. Dlatego podjęto tam działania dla rozwoju turystyki, aktywizowano lokalną produkcję (mleczarstwo, wydobycie i artystyczną obróbkę granitu). Sardynia jest zatem przykładem regionu, który w bardzo dobry sposób wykorzystał najpierw wsparcie zewnętrzne, by w kolejnych okresach przekształcić gospodarkę wykorzystując zasoby lokalne. W dużo gorszej sytuacji gospodarczej dzisiaj są duże i gęsto zaludnione regiony Południa (Kampania, Kalabria, Sycylia, Apulia), mimo że nie brakuje tam dobrze prosperujących przedsiębiorstw (firma meblowa Natuzzi z Santeramo in Colle k. Altamury). Realizowane są też programy rewitalizacyjne o istotnym znaczeniu dla turystyki (rewitalizacja Bari, projekty rewaloryzacji na Płw. Salentyńskim). Ponadto inwestycje endogeniczne ograniczają się do sektora rolno-spożywczego (fabryki makaronów, przemysł konserwowy), garbarstwa, rzemiosła, tkactwa, czyli sektorów o niskim poziomie innowacyjności. Odczuwa się deficyt odpowiedniej polityki państwa i konkretnego wsparcia dla rozwoju przemysłu rolno-spożywczego i konserwowego na Południu. Fabryki zlokalizowane na Północy chętniej pozyskują surowce z Hiszpanii lub Grecji, pozbawiając Południe nie tylko możliwości zbytu surowców, ale pod wpływem reklamy stają się silnym konkurentem dla lokalnych rynków w Mezzogiorno. Z tego względu dużym potencjałem dla rozwoju gospodarczego tych regionów mogą być inwestycje w turystykę. Jednak należy zauważyć, że Południe nie jest w stanie podążać za kapitalistycznym modelem rozwoju gospodarki, który doskonale sprawdza się w północnej części kraju. Powodem tego jest stopniowe wyludnianie się Południa, które mimo wysokiego wskaźnika urodzeń, od zjednoczenia kraju notuje zwiększanie się emigracji nie tylko na Północ, ale w ostatnich dziesięcioleciach w coraz większym stopniu także za granicę (Noviello, 2021).

Pod względem poziomu i tempa rozwoju gospodarczego Włochy, zgodnie z rozpowszechnioną w literaturze narracją, dzielą się na Pierwszą, Drugą i Trzecią Italię. Pierwsza Italia to regiony północno-zachodnie, najbogatsze, Druga Italia to Mezzogiorno, natomiast Trzecia obejmuje regiony północno-wschodnie i środkowe. Z upływem lat różnice ekonomiczne między Pierwszą i Trzecią Italią stają się coraz mniejsze, co sprawia, że coraz częściej mówi się tylko o dwóch Italiach - Północnej i Południowej. Północne i środkowe Włochy to obszar, który gospodarczo stanowi ważny składnik systemu gospodarczego Europy. Sieci silnych powiązań łączą z gospodarką europejską zarówno wielkie liguryjskie przedsiębiorstwa wspomagane przez państwo, silne firmy lombardzkie, jak i małe i średnie przedsiębiorstwa usługowe Trydentu itd. Na Południu gospodarka ma zupełnie odmienną formę, którą opisuje się za pomocą takich pojęć, jak „kapitalizm wspomagany”, „kapitalizm polityczny”, czy też „dysfunkcjonalny kapitalizm państwowy”. W tej części kraju mówi się o ekonomii przestępczej, co potwierdza wspomnianą dysfunkcję kapitalizmu państwowego. Jednak i tutaj nie brakuje przykładów dobrze prosperującego „kapitalizmu wspomaganego”. 


\section{PODSUMOWANIE I WNIOSKI}

Interwencjonizm następujących po sobie rządów włoskich w XX wieku wykazał, że podjęte działania zdecydowanie wpłynęły na rozwój gospodarczy kraju, ale nie do końca w konfiguracji, jakiej oczekiwano i jaka byłaby najbardziej korzystna dla gospodarki całego kraju. Najważniejsze wnioski obejmują następujące zagadnienia:

- przymusowa industrializacja południowej części kraju, która wymagała ogromnych nakładów inwestycyjnych w postaci zapewnienia kapitału społecznego czy infrastruktury drogowej okazała się mało efektywna (upadek zakładów), a ponadto przyczyniła się do degradacji krajobrazu i problemów ekologicznych (zanieczyszczenia);

- finanse przeznaczone na zasilenie gospodarki Południa w znacznej części zostały przekierowane do zakładów na Północy, które zapewniając dostawę maszyn i specjalistycznego sprzętu do powstających na Południu fabryk, stały się realnym beneficjentem tych środków;

- na Południu zbyt wiele środków finansowych przeznaczono na znacznie mniej rentowne rolnictwo, a także prowadzono politykę opóźnionej industrializacji, co powodowało znaczną przewagę konkurencyjną przedsiębiorstw z Północy zarówno na rynku krajowym, jak i w eksporcie,

- podczas realizacji programów i planów naprawczych IRI nie dotrzymało postulatów odnośnie do zmniejszenia dysproporcji między północną a południową częścią Italii, co obecnie, w dobie gospodarki wolnorynkowej, stawia regiony Południa w bardzo niekorzystnej sytuacji gospodarczej i powoduje powiększanie się problemów społecznych (m.in. emigracja, ucieczka wykształconych umysłów).

Biorąc pod uwagę, że przemysł i usługi należą do podstawowych czynników rozwoju społecznego, gospodarczego i kulturowego układów przestrzennych, a zwłaszcza tych lokalnych i regionalnych, należy mieć na uwadze zmieniające się reguły gospodarowania, wzrost wpływu procesów globalizacji i postępu cywilizacyjnego (Zioło, 2017). Z tego powodu przed gospodarką Włoch stoi bardzo trudne zadanie polegające na podjęciu konkretnych, a nie eksperymentalnych działań mających na celu harmonizację w rozwoju gospodarczym na poziomie regionów przy uwzględnieniu wymienionych zależnych. Jest to o tyle istotne, że zbyt duże dysproporcje społeczno-gospodarcze, jakie obserwuje się we Włoszech powodują nasilenie się negatywnych procesów, które przy mniejszym natężeniu nie stanowiły do tej pory powodu do obaw. Istotna w tym procesie jest aktywizacja narzędzi polityki centralnej, z większą przychylnością i kontrolą na Południu, gdyż realna obecność państwa zapewnia większe poczucie bezpieczeństwa i wsparcia, co oznacza większą skłonność przedsiębiorców do podjęcia działalności gospodarczej. Jednak we Włoszech, w ostatnich dziesięcioleciach dość często następujących po sobie rządów, obserwuje się, że jedne bardziej optowały za polityką regionalną i takową gospodarką, inne natomiast za gospodarką bardziej scentralizowaną. W efekcie rząd pozostający stosunkowo krótko przy władzy, zamiast dążyć do opracowania spójnego programu rozwoju gospodarczego kraju, niejako eksperymentalnie przyzwala na kolejne referenda odnośnie do polityki regionalnej. I tak, w 2016 roku odbyło się istotne referendum odnośnie do wprowadzenia zmian w Konstytucji (reforma Renzi-Boschi) dotyczących m.in. likwidacji prowincji czy zmian liczby kompetencji przyznanych państwu i regionom (Gorlani, 2017). Po jego niepowodzeniu i upadku rządu Matteo Renzi, niektóre regiony (Lombardia, Wenecja Euganejska i Emilia-Romania) 
podjęły starania w kierunku wdrożenia tzw. zróżnicowanego regionalizmu (regionalismo differenziato), który polega na różnicach w przydzieleniu regionom różnej liczby kompetencji ${ }^{6} \mathrm{w}$ zależności od kondycji gospodarczej regionu. I tak wspomniane powyżej regiony podjęły (w sposób tajny) działania zmierzające ku przekazaniu im wszystkich (Lombardia i Wenecja Euganejska) lub części (Emilia-Romania) kompetencji przypisanych w konstytucji państwu. Starania te są motywowane występowaniem tzw. residuo fiscale, czyli różnicą między podatkami płaconymi przez obywateli określonego terytorium (administracyjnego) na rzecz skarbu państwa a środkami, jakie są temu terytorium przekazywane przez państwo w celu zapewnienia obywatelom podstawowych usług. Włoski ekonomista Giannola przypomina, że w państwach unitarnych nie można mówić o residuo fiscale, gdyż stosunek podatkowy zachodzi między państwem a obywatelem, a nie określonym terytorium (Giannola, Petraglia, Scalera, 2018). W przeciwnym wypadku oznaczałoby to, że część społeczeństwa ma prawo do większej ilości i lepszej jakości usług ze względu na miejsce zamieszkania, co jest niezgodne z Konstytucją i oznacza upadek państwa socjalnego.

W lutym 2018 roku wychodzący ze sceny politycznej rząd Paolo Gentiloni zatwierdził wstępne umowy z tymi regionami, które są przekonane, że zyskując pełną autonomię, mają możliwość uzyskania większych dochodów poprzez zatrzymanie całości podatków na ich terytoriach. Mechanizm ten został nazwany przez ekonomistę Gianfranco Viesti „secesją bogatych”, gdyż wspomniane regiony wytwarzają ponad 50\% włoskiego PKB.

Według badań ekonomistów Giannoli i Stornaiuola (2018) regiony, które będą wdrażać zróżnicowany regionalizm (nazwany zamiennie zróżnicowanym federalizmem), odnotują wzrost ex post udziału środków wydatkowanych i zarządzanych przez ich administrację w porównaniu z sytuacją ex ante (+106 miliardów dla Lombardii, +41 miliardów dla Wenecji Euganejskiej i +43 miliardów dla Emilii-Romanii), przy czym nastąpi zmniejszenie o taką samą ilość środków zarządzanych bezpośrednio przez administrację centralną. Przykład ten wskazuje, jak istotna jest rola państwa dla prowadzenia jednej i przede wszystkim spójnej polityki gospodarczej, zwłaszcza w kraju, który ze względu na występujące problemy ekonomiczne nie może faworyzować i wprowadzać specjalnych uchyleń względem tylko wybranych regionów kraju. Z tego względu państwo powinno w pełni korzystać z instrumentów władzy i koordynować decyzje w regionach mając na uwadze i respektując reguły gospodarki wolnorynkowej.

\section{Literatura \\ References}

Amatori, F., Colli, A. (1999). Impresa e industria in Italia dall'Unità a oggi. Venice: Marsilio.

Commissione Parlamentare Antimafia-Legislatura VI. (2021, 10 września). Disegni di legge, relazioni e documenti-Capitolo primo-la genesi della mafia. Pozyskano z https://archiviopiolatorre.camera.it

Czuma, Ł. (1969). Wpływ czynników instytucjonalnych na rozwój gospodarczy regionów opóźnionych we Włoszech. Ruch Prawniczy, Ekonomiczny i Socjologiczny, 31(1), 287-309.

${ }^{6}$ Listę kompetencji określa art. 117, ust. 3 konstytucji Włoch, wśród których znajdują się m.in. stosunki międzynarodowe i stosunki z UE, ochrona i bezpieczeństwo pracy, edukacja, ochrona zdrowia, porty i lotniska cywilne, duże sieci transportowe i nawigacyjne. 
Felice, E. (2007). Divari regionali e intervento pubblico. Per una rilettura dello sviluppo in Italia. Bologna: il Mulino, 120-123.

Felice, E. (2010). Regional development: reviewing the italian mosaic. Journal of Modern Italian Studies, 15(1), 64-80.

Fenoaltea, S. (2007). I due fallimenti della storia economica: il periodo post-unitario. Rivista di politica economica, 3-4, 341-358.

Giannola, A., Stornaiuolo G. (2018). Un'analisi delle proposte avanzate sul "federalismo differenziato". Rivista economica del Mezzogiorno, 1-2, 5-52.

Giannola, A., Petraglia, C., Scalera, D. (2018). Residui fiscali, bilancio pubblico e politiche regionali. Economia pubblica: mensile di studi e d'informazione del Ciriec, 1-25. doi: 10.3280/EP2017002003

Gorlani, M. (2017). Quale futuro per le Province dopo l'esito del referendum costituzionale del 4 dicembre 2016. Federalismi.it Rivista di diritto pubblico italiano, comparato, europeo, 5, $1-28$.

Istat. (2019). Conti economici. Pozyskano z Conti economici territoriali - anni 2017-2019 (istat. it) (dostęp 10.10.2021).

Janek, J. (2016). Rola sektora państwowego w powojennym rozwoju Włoch oraz w okresie boomu gospodarczego w latach 50. i 60. XX wieku. Kwartalnik Kolegium Ekonomiczno-Społecznego. Studia i Prace, 1, 139-172. https://doi.org/10.33119/KKESSiP.2016.1.6

Janek, J. (2018). Społeczne i ekonomiczne przesłanki sycylijskiego separatyzmu od zjednoczenia Włoch do połowy XX wieku. Mafia a kwestia niepodległości Sycylii. Kwartalnik Kolegium Ekonomiczno-Społecznego. Studia i Prace, 2, 121-136.

Majorek, A. (2017). Partycypacja społeczna jako wehikuł rozwoju. Studia Komitetu Przestrzennego Zagospodarowania Kraju PAN, 226-234.

Noviello, M. (2018). Rola hutnictwa w rozwoju regionalnym Kampanii (Włochy) w XX wieku. Prace Komisji Geografii Przemysłu Polskiego Towarzystwa Geograficznego, 32(3), 186-200. doi: https://doi.org/10.24917/20801653.323.12

Noviello, M. (2021). The Great Migration of Italians to the USA after the Unification of the Country. W: K. Ziółkowska-Weiss (red.), Miniorities in the USA. Past and Present. Kraków: Wydawnictwo Naukowe Uniwersytetu Pedagogicznego, 139-151.

Pawlewicz, K., Pawlewicz, A. (2010). Rola partycypacji społecznej na rzecz zrównoważonego rozwoju obszarów wiejskich. Zeszyty Naukowe Szkoły Głównej Gospodarstwa Wiejskiego. Ekonomika i Organizacja Gospodarki Żywnościowej, 83, 71-80.

Pelaggi, S. (2016). L'altra Italia. Emigrazione storica e mobilità giovanile a confronto. Roma: Edizioni Nuova Cultura.

Pietraszko-Furmanek, I. (2012). Partycypacja społeczna w środowiskach lokalnych. Kraków: Krakowskie Towarzystwo Edukacyjne - Oficyna Wydawnicza AFM. (Rejony Humanistyki; 8).

Putnam, R.D. (1993). Making Democracy Work. Civic Traditions in Modern Italy. Princeton: University Press.

Sinigaglia, O. (1948). The future of the Italian iron and steel industry. PSL Quarterly Review, 1(4). Słupik, S. (2016). Rola partycypacji społecznej w kreowaniu lokalnego zrównoważonego rozwoju. Prace Naukowe Uniwersytetu Ekonomicznego we Wrocławiu, 454, 252-264.

Stokowska, D. (2006). Uwarunkowania polityki regionalnej na przykładzie Włoch. Studia i Materiały. Wydział Zarzadzania Uniwersytet Warszawski, 2, 30-42.

Zioło, Z. (2017). Wpływ przemysłu i usług na rozwój społeczno-gospodarczy układów przestrzennych. Prace Komisji Geografii Przemysłu Polskiego Towarzystwa Geograficznego, 31(4), 7-24. doi: https://doi.org/10.24917/20801653.314.1

Monika Noviello, mgr, asystentka, Uniwersytet Pedagogiczny w Krakowie, Instytut Geografii, Katedra Przedsiębiorczości i Gospodarki Przestrzennej, absolwentka Instytutu Geografii Uniwersytetu Pedagogicznego w Krakowie (2011) oraz Wydziału Architektury i Urbanistyki Uniwersytetu Federico II w Neapolu (2014). Doktorantka w Instytucie Geografii Uniwersytetu Pedagogicznego. Zainteresowania badawcze autorki dotyczą historii i rozwoju regionalnego Włoch, urbanistyki i planowania przestrzeni miejskich.

Monika Noviello, MSc, Pedagogical University of Krakow, Institute of Geography, Department of Entrepreneurship and Spatial Management. She has graduated from the Pedagogical University of Krakow (2011) and the Faculty of Architecture and Urban Planning at the University of Federico II in Naples (2014). PhD student 
in the Institute of Geography at the Pedagogical University of Krakow, Department of Entrepreneurship and Spatial Management. Her research interests are connected to history and regional development of Italy and urban planning.

ORCID: https://orcid.org/0000-0003-4634-6296

\section{Adres/address:}

Uniwersytet Pedagogiczny w Krakowie

Instytut Geografii

Katedra Przedsiębiorczości i Gospodarki Przestrzennej

ul. Podchorążych 2

30-084 Kraków, Polska

e-mail: monika.noviello@up.krakow.pl 